\title{
UM LUGAR CHAMADO BRICK LANE: DA SUBALTERNIDADE À CONSTRUÇÃO DE UMA IDENTIDADE FEMININA INDEPENDENTE, MODERNA E INSUBORDINADA
}

\author{
ROCHA, Sara Almieira da ${ }^{1}$ \\ ALVES, Elis Regina Fernandes ${ }^{2}$
}

RESUMO: Este artigo analisa a personagem feminina Nazneen no romance Um lugar chamado Brick Lane (2003), de Monica Ali, com o objetivo principal de verificar seus passos para sua emancipação, o modo como ascende como mulher, tornando-se independente e insubmissa. Em contraponto com a ascensão de Nazneen, verifica-se também a estagnação de sua irmã, Hasina, que por ter ficado em uma sociedade com o discurso patriarcal mais acentuado, não consegue conquistar sua autonomia. A metodologia de investigação consiste em textos teóricos que discutem o papel da mulher na sociedade, o surgimento das lutas e o feminismo literário, como meio de mulheres escritoras apresentarem e representarem personagens femininas desafiadoras, independentes e insubordinadas. Para sustentar essas contestações, o trabalho baseia-se nos autores: Bourdieu (2002), Beauvoir (1980 I e II), Wollstonecraft (2016), Showalter (2014), dentre outros. Os resultados do trabalho mostram que a subjetividade da protagonista é construída a partir da evolução de uma mulher submissa ao marido, para uma mulher independente, insubmissa e moderna. Entende-se que Nazneen apenas consegue construir sua subjetividade porque é inserida numa sociedade mais liberal que a sociedade muçulmana, uma vez que Hasina, por ficar nesta sociedade, não consegue escapar das imposições patriarcais.

PALAVRAS-CHAVE: Crítica literária feminista, Subjetividade feminina, Um lugar chamado Brick Lane.

\section{BRICK LANE: FROM SUBALTERNITY TO BUILT OF AN INDEPENDENTE, MODERN AND UNRULY FEMALE INDENTITY}

\footnotetext{
${ }^{1}$ Graduanda do curso de Letras - Língua Portuguesa e Língua Inglesa da Universidade Federal do AmazonasUFAM, bolsista de PIBIC. E-mail: saraalmieira2@gmail.com

${ }^{2}$ Professora da Universidade Federal do Amazonas - UFAM, no curso de Letras, atuando como coordenadora de curso. E-mail: elisregi@ufam.edu.br 


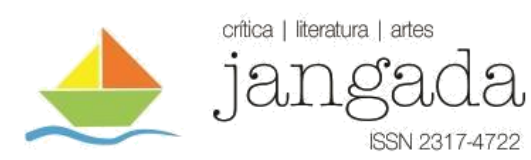

ABSTRACT: The female character Nazneen is analyzed in the novel Brick Lane (2003), by Monica Ali. The aim is to verify her steps towards her emancipation, how she ascends as a woman, becoming independent and unruly. Besides, in contrast with Nazneen's ascension, we also verify the stagnation of her sister, Hasina, who remained in a society with a stronger patriarchal discourse, she could not achieve her autonomy. The methodology of this work consists on theoretical texts that discuss the woman's role in society, the appearance of feminist struggles, as well as the literary feminism as a way of woman writers present and represent challenging, independents and rebellious female characters. To support these discussions, the work is based on the authors: Bourdieu (2002), Beauvoir (1980 I and II), Wollstonecraft (2016), Showalter (2014), and others. The results show that the protagonist's subjectivity is built from the evolution of a submissive woman to an independent, unruly and modern woman. Nazneen just manages to build her subjectivity because she is starts to live in a more liberal society than the Muslim society, while Hasina, who remains in a Muslim society, could not escape from patriarchal impositions.

KEYWORDS: Feminist criticism, Female subjectivity, Brick Lane.

\section{INTRODUÇÃO}

O presente artigo analisa a protagonista Nazneen, no romance Um lugar chamado Brick Lane (2003), escrito por Monica Ali, verificando seus passos para sua emancipação, o modo como ascende como mulher, tornando-se independente e insubmissa. Além disso, discute o papel histórico da mulher e como ocorreram os primeiros feminismos, denominação que se dá às lutas nas diversas áreas, para mudar a condição à qual as mulheres estavam relegadas. $\mathrm{O}$ trabalho discute, ainda, o feminismo na literatura, os desafios que a escrita de autoria feminina enfrentou para poder ser reconhecida no cânone tradicionalmente masculino. Por último, busca-se comparar a ascensão de Nazneen como mulher na sociedade londrina com a estagnação de sua irmã, Hasina, em Bangladesh.

Análises literárias sob a perspectiva da crítica feminista tem grande relevância para desconstruir e denunciar a posição de subalternidade à qual as personagens femininas e escritoras estavam relegadas, ultrapassando a barreira do silêncio e, lentamente, se inserindo em diversos campos. A crítica feminista tem por principal objetivo estudar a literatura sobre mulheres e feitas por mulheres, compreendendo como houve a resistência pela escrita numa sociedade inteiramente dominada pelos valores patriarcais. Justifica-se esse artigo por tematizar, justamente, aquilo que o feminismo literário utiliza como premissa na análise da 


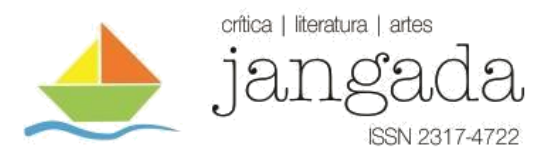

figuração feminina: a influência negativa das sociedades patriarcais à ascensão feminina. $\mathrm{O}$ contraste entre as duas personagens aqui analisadas servirá para exemplificar como a produção literária feita por mulheres busca assumir sua própria voz, sua linguagem e seu discurso, construindo textos a partir de suas próprias experiências e contextualização de suas sociedades.

Este trabalho utilizará uma metodologia de procedimento bibliográfico, já que será realizado um levantamento teórico acerca do papel socialmente atribuído à mulher nas sociedades patriarcais, bem como do feminismo como fenômeno de luta e independência das mulheres, e sua vertente na literatura. Serão base teórica para essa discussão, autores como Bourdieu (2002), Beauvoir (1980), Wollstonecraft (2016), Showalter (2014), Virginia Woolf (1990), Kate Millett (1970), dentre outros. Após o entendimento da evolução do feminismo e sua ascensão como teoria literária, o romance em questão será analisado, e suas personagens comparadas, de modo a perceber como a figuração das duas personagens exemplificam mulheres em condições diferentes de independência.

\section{O PAPEL DA MULHER NA SOCIEDADE E SEUS PRIMEIROS FEMINISMOS}

As mulheres, ao internalizarem os discursos patriarcais como ideais, também cooperaram para o estabelecimento das diferenças sociais que foram implantadas, disfarçadamente, sendo camufladas pela religião, pela linguagem, pelas ações, pelos ensinamentos na escola, entre outras vias simbólicas, sem que as vítimas percebessem, “[...] resultante daquilo que eu chamo de violência simbólica, violência suave, insensível, invisível a suas próprias vítimas [...]” (BOURDIEU, 2002, p. 6). Ao tornarem-se mães, as mulheres acreditavam que, por serem biologicamente mais fracas, não podiam trabalhar fora de casa, deviam cuidar dos filhos, porém, ao cuidar dos filhos, isso as impediam de trabalhar, fazendo válidas as visões masculinas, pois esse ciclo era fixado pelos homens. Percebe-se que são discursos que se sustentam, ou seja, um alimenta o outro, fazendo com que as mulheres inseridas nessa sociedade não percebam, porque esses discursos aceitos como verdades absolutas desarticulam a visão autônoma das mulheres.

Considerado como um ciclo contraditório, as mulheres são dominadas e não conseguem revidar, já que não se percebem como vítimas, e os homens o intensificam com seus pronunciamentos, como por exemplo, eles "exigem" casar-se com mulheres dignas e obedientes, e como estas são dependentes e ensinadas a almejar o casamento, elas acabam seguindo esses preceitos, validando as maneiras de ver e de pensar do homem: "os dominados 


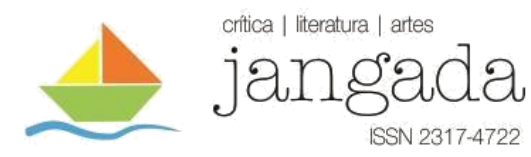

aplicam categorias construídas do ponto de vista dos dominantes às relações de dominação, fazendo-as assim ser vistas como naturais.” (BOURDIEU, 2002, p. 23)

Saffioti afirma que "o sexismo, não é somente uma ideologia, reflete também, uma estrutura de poder, cuja distribuição é muito desigual, em detrimento das mulheres" (2015, p. 37), essa estrutura de poder é construída socialmente pelos homens, na qual são os detentores do poder, fez o patriarcado prevalecer; este também, baseado no controle do medo, fez as mulheres acreditarem que era mais fácil seguir os princípios postos do que opor-se a eles.

$\mathrm{Na}$ classe média, os homens na juventude eram preparados para exercer várias profissões, ao contrário das mulheres que se dedicavam inteiramente ao casamento e à maternidade, para eles o casamento não era considerado o grande feito de suas vidas, pois eram ensinados a desenvolver suas capacidades mentais (WOLLSTONECRAFT, 2016). As mulheres não podiam ter relações sexuais antes do casamento, pois a virgindade era exigida. Se elas tivessem relações sexuais antes do casamento eram punidas pela sociedade, sendo renegadas como esposas e muitas vezes expulsas de casa pelo próprio pai. E como estas mulheres não tinham escolhas, já que não se encaixavam nos padrões que a sociedade exigia, viam a prostituição como o único caminho.

Além de serem educadas para seguir os princípios masculinos e serem honradas seguindo as ordens postas, as mulheres também eram educadas a conviver com a desonra, "uma mulher que perdeu toda sua honra imagina que não pode afundar mais, e que é impossível recuperar sua posição anterior; pois nada pode limpar essa mancha" (WOLLSTONECRAFT, 2016, p. 100). Com isso, as mulheres que não se adequassem às regras sexistas eram reduzidas à prostituição, elas acreditavam que eram incapazes de realizar outra atividade de subsistência que não fosse usando seus corpos, e uma vez que se denominassem prostitutas, acreditavam que não existia saída.

O prazer sexual feminino também era proibido, pois membros da igreja o consideravam uma ação imoral e vergonhosa, apenas o homem tinha esse direito. Matos e Soihet reiteram que “o prazer feminino é negado, até mesmo reprovado: coisa de prostitutas” (2003, p. 16). Assim, é possível perceber o quanto as mulheres foram coibidas até nas relações sexuais, pois sua conduta sexual era cobrada socialmente e como a mulher tinha apenas a honra como benefício, ela seguia o padrão e os valores impostos pela religião.

Nos países mulçumanos, a situação das mulheres não era diferente, visto que a posição central era ocupada pelos homens e as mulheres ficaram relegadas a uma posição secundária. Pinto esclarece que "segundo o alcorão o homem é naturalmente propenso ao sustento material 


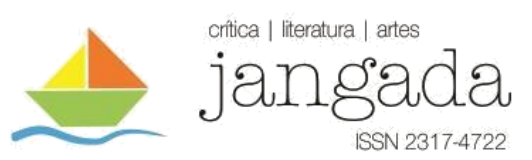

da família, enquanto as mulheres nasceram para exercer a maternidade.” (2010, p. 51). O povo islâmico segue as interpretações do alcorão, livro sagrado do profeta Maomé, em que seus fundamentos são aceitos como verdades absolutas, sendo reflexo de crenças, valores, princípios morais e estéticos (SILVA, 2014). Por isso, é difícil ir contra a tradição religiosa e contra os deveres estabelecidos por esta.

O Islã é uma religião que preza pelo cumprimento das obrigações morais que compõem a sua tradição religiosa. Todo mulçumano aprende a seguir os pilares que constitui a sua tradição e aprendem as práticas que lhe são incutidas desde seus nascimentos, como orar, jejuar e obedecer às outras regras islâmicas, contribuindo para a consolidação desta religião; estas práticas vivenciadas pelos muçulmanos contribuem para entender como estes vivenciam a religião de forma relativamente prescritiva. (PINTO, 2014). A realização das normas leva o povo islâmico a acreditar na salvação, por isso, as mulheres seguem a conduta exigida, uma vez que também está ligado à sua honra. Elas carregam o fardo de manter a tradição, porque são delas que nascem os futuros mulçumanos, os homens admiram e valorizam as mulheres por esse fato, porém, de forma ambígua, já que elas são dignas e honradas quando estão em casa dedicadas aos filhos, como confirma Truzzi: "as funções destinadas às mulheres são reconhecidas como de fundamental importância para as futuras gerações muçulmanas, pois é das mulheres que nascem os futuros muçulmanos, tornando-as grandes responsáveis pela manutenção da tradição religiosa." (2008, p. 46-47).

Assim, as mulheres mulçumanas que não seguem a tradição são malvistas, pois o discurso religioso domina essa sociedade: "gerar e educar filhos muçulmanos são compreendidos como ações de extremo valor no Islã, e quem não é capaz de fazê-lo acaba tendo a sua imagem prejudicada frente à sociedade.” (TRUZZI, 2008, p. 47). Entende-se que se elas se oporem a esse papel e escolherem não terem filhos ou se comportarem como homens, elas são rejeitadas e até violentadas. Com isso, as mulheres mulçumanas viviam em situação de subalternidade, restritas de direitos políticos, sociais e civis, submetidas não só ao sistema patriarcal, mas religioso também, o que, de certa forma, não se difere da situação da mulher cristã. (SILVA, 2014).

As reinvindicações pelos direitos femininos começaram mais firmemente no século XVIII, um exemplo disso são as escritoras Olympe de Gouges e Mary Wollstonecraft, que lutaram pela participação feminina na sociedade. A partir disso, as mulheres da Europa, principalmente as francesas, promoveram encontros para discussão dos direitos femininos, e estes encontros acabaram por ser denominados de "feminismos", surgidos no final do século 


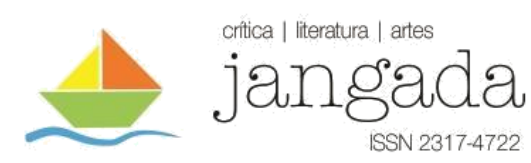

XIX: "Em 1884, a francesa Hubertine Auclert escreveu às feministas norte-americanas, que lhe pediam para participar da criação de um Conselho Internacional de Mulheres (International Council of Women: ICW)." (MICHEL, 1982, p. 65). Assim, elas faziam reivindicações por direitos básicos, como a ocupação das profissões consideradas masculinas, participação social e política, educação em todos os níveis, entre outros.

A partir de então, todos os movimentos que lutavam pelos direitos das mulheres eram considerados feminismos, mesmo que não se dominassem como tal. Perrot concorda com essa afirmação ao expor que: "em sentido muito amplo, "feminismo", "feministas" designam aqueles e aquelas que se pronunciam e lutam pela igualdade dos sexos.” (2007, p. 154). Assim, todas as pessoas que se opõem à sociedade patriarcal, lutando pela igualdade dos direitos civis, políticos e sociais entre os sexos, é considerada feminista.

$\mathrm{O}$ advento das guerras mundiais permitiu que as mulheres se firmassem no mercado de trabalho, pois houve a necessidade de as indústrias contratarem mais mão de obra, quando vários homens foram mutilados e mortos nas guerras. As principais fábricas que contratavam mulheres eram as de fiar algodão, as de costura, e as de lavagem de tecidos: "[...] há oferecimentos maciços de emprego nas indústrias do algodão, da lã e da seda; as mulheres são, principalmente, utilizadas na fiação e na tecelagem. Os patrões muitas vezes as preferem aos homens. "Trabalham melhor e mais barato." (BEAUVOIR, 1980I, p. 149). Mas, mesmo trabalhando, elas continuavam subordinadas, pois recebiam os menores salários, os empregos mais humilhantes e também havia uma exclusão no trabalho, em que elas ocupavam vagas de trabalho que coincidiam com suas práticas domésticas.

Perrot (2007) compreende que outro modo de as mulheres ganharem dinheiro foi montando ateliês e trabalhando em casa, em que elas alugavam ou compravam uma máquina de costura, contribuindo para o orçamento doméstico. Dessa forma, "a costura foi um imenso viveiro de empregos, de ofícios, de qualificações para as mulheres, e isso durante séculos" (PERROT, 2007, p. 121). A costura também foi uma forma de muitas mulheres ganharem independência e reconhecimento social por seu trabalho, isso ocorria porque as mulheres tinham uma habilidade manual muito grande.

Conforme iam ganhando espaço na sociedade, as mulheres, também, iam conquistando direitos e liberdades, sobretudo, com as lutas feministas que abriram caminho para que isso ocorresse, porque enquanto a liberdade foi dada aos homens, as mulheres tiveram que conquistar a sua. De início os movimentos feministas buscaram os direitos democráticos, como estudar, votar, trabalhar, se divorciar, entre outros. 


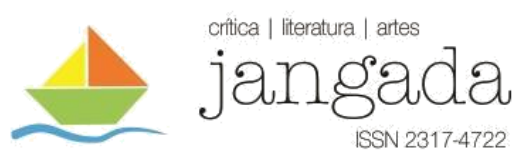

Posteriormente, esses movimentos lutaram pela libertação sexual, pois com a invenção do anticoncepcional na década de 60: "pela primeira vez as mulheres puderam realizar suas tentativas milenares de separar sexualidade e procriação" (MICHEL, 1982, p. 81). Deste modo, as mulheres passaram a ter a opção de ter filhos ou não, e os homens não tinham mais motivos para mantê-las em casa. Simone de Beauvoir, com a publicação de O segundo sexo (1949) influenciou essas mulheres nessa luta, pois sua obra desconstruía o papel, até então, convencionado socialmente para a mulher.

Assim sendo, as mulheres começam a atuar em diversos campos sociais, como por exemplo o literário, no qual são desconstruídos os papéis tradicionais masculinos e femininos do cânone literário. Essa luta na literatura também é marcada por uma conquista árdua e lenta, porque até o século XIX, apenas a escrita masculina era reconhecida pelos críticos literários. A partir de então, a sociedade sexista precisou conviver com a cultura antissexista, em que as mulheres provaram que a condição biológica feminina nunca interferiu no seu papel social como cidadãs.

\section{O FEMINISMO NA LITERATURA}

O sexo masculino não dominou apenas o meio social, mas o literário também, firmando-se como superior até na escrita, porque até meados do século XVIII, a imensa maioria do público leitor era formando por homens e, consequentemente, apenas eles escreviam, porque tinham a oportunidade de receber uma educação de qualidade e ainda frequentavam a universidade, enquanto as mulheres desempenhavam papéis impostos, sendo boas esposas e mães dedicadas. Assim, as mulheres não tinham como se inserir no ramo literário se a educação para elas era negada. Showalter concorda ao afirmar que: "Women writers were deprived of education because of their sex, not because of their class." (2014, p. 34), portanto, as mulheres eram vistas pelo seu sexo e não pelas obras que produziam e nem a que classe pertenciam, diferente dos homens, que a todo momento eram vistos como criadores, não importando sua classe, firmando, ainda mais, a desigualdade entre os sexos.

Com a entrada das mulheres na Universidade, elas começaram a entender as relações de poder, e também a compreender como o saber estava ligado a este, descobrindo como o efeito dessas relações causavam a exclusão das vozes femininas para manter a ordem social da sociedade sexista. Por isso, as feministas propagavam a importância da integração das mulheres 


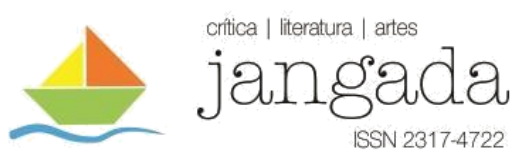

no meio universitário, para que compreendessem os modos de silenciamento e falta de representatividade a que estavam socialmente impostas.

Esse atraso das mulheres no sistema universitário gerou reflexos no campo profissional, principalmente, na questão salarial, como é possível perceber até hoje. Millett confirma que "o acesso da mulher ao ensino superior, à igualdade de possibilidades em relação ao homem, constituiu um dos principais objectivos das feministas." (1970, p. 29), pois, para conquistar o espaço profissional e, também, introduzir-se no meio literário, composto apenas por homens, as mulheres precisavam enfrentar todos os obstáculos impostos ao seu sexo, sobretudo, as contradições dos discursos patriarcais, para que assim frequentassem uma universidade. Com isso, teriam os mesmos conhecimentos e, consequentemente, as mesmas possibilidades que os homens tinham.

Foi desagradando a sociedade, especialmente, os homens, que as mulheres adentraram a literatura. Ao serem proibidas de publicar obras literárias por causa de seu sexo, elas adotaram técnicas para que suas obras fossem aceitas e lidas pela sociedade e críticos literários, como foi o caso da adoção dos pseudônimos masculinos. Showalter confirma: "The height and the trademark of feminine role-playing was the male pseudonym. Primarily a way of obtaining serious treatment from critics, the pseudonym also protected women from the righteous indignation of their own relatives. (2014, p. 47-48). Portanto, eram estratégias que garantiam segurança às mulheres, tanto do julgamento da sociedade quanto da família, e ainda beneficiavam sua entrada no mundo das artes. Era criada uma ideia de denúncia e resistência por meio das obras produzidas por mulheres, porque, em suas histórias, elas retratavam personagens femininas questionadoras, corajosas e desafiadoras. A partir de então, os heróis tinham perdido seu lugar para as heroínas, retratadas como mulheres fortes e donas de seus destinos.

As críticas literárias que começaram a estudar os trabalhos literários das mulheres analisavam e buscavam compreender como houve a resistência dessa escrita numa sociedade inteiramente dominada pelos valores sexistas. $\mathrm{O}$ objeto de estudo da crítica feminista era as mulheres, dado que procuravam revisar e criticar a escrita feita por mulheres, como a ensaísta norte americana Elaine Showalter, que investigou a literatura produzida por mulheres inglesas durante o período de 1840 a 1960, e chegou à conclusão de que todas as chamadas subculturas literárias passaram por três fases:

First, there is a prolonged phase of imitation of the prevailing modes of the dominant tradition, and internalization of its standards of art and its views on 


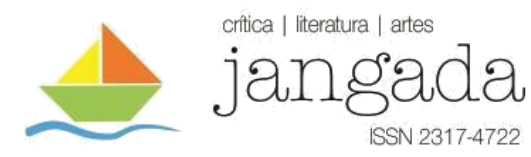

social roles. Second, there is a phase of protest against these standards and values, and advocacy of minority rights and values, including a demand for autonomy. Finally, there is a phase of self-discovery, a turning inward freed from some of the dependency of opposition, a search for identity. An appropriate terminology for women writers is to call these stages, Feminine, Feminist and Female. (SHOWALTER, 2014, p. 11)

Dessa forma, inicialmente, as escritoras ainda imitavam os padrões masculinos, em que criavam personagens estereotipadas, o que ocorria por causa da internalização das ideologias machistas predominantes, em que as mulheres produziam romances aceitos pela sociedade. Showalter ressalta que a duração dessa fase, denominada feminina, vai de 1840 até 1880 . No entanto, apesar de Showalter especificar datas para a durabilidade das fases literárias, ela própria esclarece não haver datas fixas para esta classificação: "I have begun with the women born after 1800, who began to publish fiction during the 1840s when the job of the novelist was becoming a recognizable profession.” (2014, p. 14). Portanto, ela adaptou essas fases com o momento em que estava ocorrendo a fluidez da literatura de autoria feminina e o reconhecimento dessas escritoras como profissionais. Assim, o uso das datas é uma questão didática para compreender a evolução histórica dos movimentos literários femininos, mas a literatura, como meio de dar curso aos pensamentos humanos, não pode ser restrita há anos específicos.

Pode-se evidenciar a fase feminina no romance Razão e Sensibilidade, de 1811, da inglesa Jane Austen. Com relação a data dessa obra, ela não está dentro do tempo especificado por Showalter da duração dessa fase, mas que mesmo assim faz parte, porque, como já explicado, não são datas fixas, mas uma questão didática. Este romance retrata a vida das irmãs Dashwood, em que Marianne é identificada por agir pela sensibilidade e Elinor pela razão. As personagens, vale ressaltar que são protagonistas, são representadas como inteligentes e ousadas, sejam agindo pela razão ou pela emoção, porque as mulheres naquela época dificilmente demonstravam algum sentimento, já que eram ensinadas a não fazer isso, então são mulheres fortes e ousadas, porém a felicidade delas ainda consistia no casamento. Nesse sentido, este romance se encaixa na fase feminina proposta por Showalter.

Da imitação, as escritoras passam a protestar, não apenas no meio social, mas no literário também e começam a romper com os padrões machistas estabelecidos, suas personagens passam a agir, lutam por seus direitos e buscam independência. Segundo Showalter, a duração dessa fase vai de 1880 até 1920 , sendo denominada de feminista. Essa fase pode ser identificada 


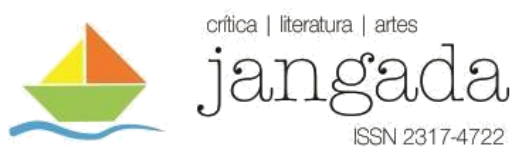

na personagem Jane Eyre, cujo romance leva seu nome: Jane Eyre, de 1847, de Charlotte Brontë, em que ela é retratada como uma heroína que busca sua independência, e que mais tarde é alcançada através do trabalho. Jane é questionadora, e para o século XIX, questionar para as mulheres é considerado uma ideia subversiva, ela tem objetivos e não aceita apenas o que lhes oferecem, é corajosa e busca a autossuficiência, contrariando a sociedade patriarcal. No fim do romance ela se casa, porém é uma escolha dela, e não era algo que sempre almejara, como as personagens da fase feminina. Portanto, é uma obra que se encaixa na fase feminista, pois a protagonista se opõe a desempenhar o papel pré-estabelecido para a mulher na sociedade e luta contra as situações que a vida lhe impõe, usando o que possui: inteligência, força e coragem.

A última fase proposta por Showalter é denominada de fêmea, ou "mulher", sua extensão vai de 1920 até os dias atuais - reforça-se, novamente, que não são datas fixas, pois obras produzidas antes dessa fase podem ser caracterizadas como à frente de seu tempo. Essa fase ocorre quando as mulheres buscam uma identidade própria, livre das ideologias patriarcais e praticam o conhecimento de si mesmas. Surge, então, personagens livres e independentes, donas de si e de suas vontades. Como exemplo dessa fase, tem-se a obra A sentinela, de 1994, de Lya Luft, em que é retratada a trajetória da personagem chamada Nora, uma mulher que tenta definir uma identidade própria. Nora tenta se fortalecer como mulher, pois tem conflitos internos e externos na sua vida desde a infância, isso decorre de diversos fatores, como a morte do pai e da irmã, e a rejeição que sofre por parte da mãe. Esses fatos levam a personagem a autoanalisar sua vida, suas escolhas, e ainda a estudar e superar seus dramas pessoais, o que a ajuda a sair de um casamento infeliz, tornando-se forte e independente e dona de si.

Com os exemplos dado em cada fase, pode-se chegar à conclusão de que as fases não precisam condizer com a data de publicação das obras, e sim com o conteúdo que cada uma discute, pois logo que os livros da fase feminista alcançaram o público, eles foram rejeitados pela sociedade conservadora.

Além disso, as fases aqui descritas não se excluem, podem-se identificar elementos das três fases, ou apenas duas delas, em uma mesma obra: "these are obviously not rigid categories, distinctly separable in time, to which individual writers can be assigned with perfect assurance. The phases overlap; there are feminist elements in feminine writing and vice versa." (SHOWALTER, 2014, p. 11). As mulheres escritoras criaram obras autênticas e originais, livrando-se das amarras opressoras da literatura masculina, pois ao participar da criação das obras literárias, elas passaram a reconstruir suas identidades, demonstrando suas capacidades de contribuição para o cânone literário. Como será verificado no romance aqui analisado. 


\section{ANÁLISE DA OBRA UM LUGAR CHAMADO BRICK LANE}

A autora da obra Um lugar chamado Brick Lane é Monica Ali, uma bangladeshiana que foi criada na Inglaterra. Ela nasceu em Daca, em 1967, porém, durante a guerra de independência de 1971, sua família se mudou para a Grã-Bretanha. Ali estudou Filosofia, Política e Economia no Wadham College, Oxford. Trabalhou com marketing em editoras e só começou a escrever contos após 1999. Seu primeiro romance foi Um lugar chamado Brick Lane, publicado em 2003. Cinco meses antes da publicação do romance, ela foi considerada uma das melhores jovens romancistas britânicas pela revista Granta de 2003. Na Grã-Bretanha, foram vendidas 150.000 cópias de seu livro, ele ainda foi traduzido para 25 idiomas. O romance também foi indicado para o Booker Prize de 2004. Depois disso, ela publicou três livros: Alentejo Azul (2006), Na cozinha (2009) e História não contada (2011). (DAS, 2015)

Um Lugar Chamado Brick Lane narra a história de Nazneen, uma jovem mulçumana, de 18 anos, que é obrigada a se casar com um homem mais velho e escolhido por seu pai. Após o casamento, ela vai morar em Londres em um pequeno apartamento, e divide a vizinhança com um bairro chamado Brick Lane. Apesar de Chanu, seu marido, ser um estranho para ela, ela se submete às exigências e vontades dele, aceitando seu novo estilo de vida. Nazneen vai se adaptando ao local e ao mesmo tempo crescendo como indivíduo autônomo. Ela tem reviravoltas na sua vida que a obrigam a tomar decisões, sem que Chanu interfira, como, por exemplo, o seu envolvimento com Karim e a escolha de permanecer em Londres quando o marido decide voltar para sua terra natal.

Em contraste com Nazneen, temos sua irmã, Hasina, que teve escolhas diferentes da sua irmã. Hasina fugiu com um homem para se casar por amor e depois teve que fugir de um casamento violento e enfrentar as circunstâncias de ser uma mulher separada numa sociedade patriarcal e preconceituosa. Os leitores apenas sabem o que acontece com ela através de cartas que ela escreve para Nazneen. Hasina reside em Daca e, por meio das cartas, é possível ter contato com o seu sofrimento, porém é como se ela não tivesse consciência da violência que vive, porque parece que ela está bem, mas coisas terríveis acontecem em sua vida.

A escritora utiliza recursos literários como a ironia, a metáfora e a analepse que fazem o leitor aprofundar-se no romance ao acompanhar a trajetória de duas mulheres mulçumanas em sociedades distintas, fazendo, ainda, a comparação com a situação real da trajetória das mulheres, na busca por espaço, reconhecimento social e independência. Percebe-se também que 


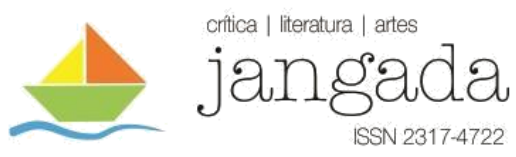

o romance é contemporâneo, uma vez que as personagens femininas possuem voz e são atuantes, isso porque até o início do século XIX os únicos protagonistas, quase sempre, eram personagens masculinos, como entendeu Millett (1970) ao analisar os papéis femininos e masculinos em obras literárias canônicas.

Inicialmente, Nazneen e Hasina vivem na mesma sociedade. A sociedade mulçumana é caracterizada por fortes tradições, pois, nos países islâmicos, o discurso patriarcal ainda é dominante e defendido pelas instituições sociais, uma vez que a religião define condições diferentes para homens e mulheres, como informou Silva (2014). Apesar de compartilharem o mesmo espaço e receberem os mesmos ensinamentos, Nazneen e sua irmã Hasina apresentam comportamentos diferenciados, porque enquanto Nazneen é obediente e comportada, Hasina é insubordinada e arrisca mais, questiona e toma decisões sem consultar o pai, como por exemplo, ela não esperou o pai fazer um casamento forçado, como ocorre na tradição mulçumana, em que o pai escolhe o marido das filhas, mesmo sem seus consentimentos.

Hasina foi ousada quando escolheu seu próprio caminho e fugiu para se casar: "Sua irmã Hasina [...] não obedecia a ninguém. Aos dezesseis anos, quando sua beleza estava quase insuportável de carregar ou mesmo de contemplar, ela fugiu para Khulma com o sobrinho do dono da serraria." (ALI, 2004, p. 14). Essa personagem parece ser uma mulher à frente de seu tempo, pois toma atitudes e faz suas escolhas sem a influência de sua tradição e ainda confronta o pai ao fugir de casa, mostrando ser audaciosa e determinada.

Nazneen, porém, é o oposto de sua irmã, pois queria seguir os passos da mãe, sendo seu reflexo como boa mãe e esposa obediente, por isso, ela deixa seu pai tomar decisões importantes em sua vida, como a escolha de seu marido: “- Abba, estou contente por você ter escolhido meu marido. Espero que eu possa vir a ser uma boa esposa, como Amma.” (ALI, 2004, p. 14). Ela desejava isso porque esse era o modelo aceitável e essencial para a sociedade patriarcal, como entendeu Beauvoir (1980 II) ao afirmar que a menina é ensinada a imitar a mãe. E, como Nazneen foi ensinada a sempre esperar que alguém superior a ela, como era o caso do pai, decidisse sobre seu futuro, ela era passiva a isso.

Mesmo que depois não gostasse do marido, o casamento era obrigatório para honrar a família: "O homem com quem ela iria se casar era velho. E tinha cara de sapo." (ALI, 2004, p. 14). Ao analisar seu futuro marido, percebe-se que ela atribui a ele as características de velho e feio, demonstrando que não queria se casar com aquele homem. Sua impressão sobre Chanu evidencia que vontades ela tinha, porém não tinha coragem de enfrentar seu pai e desobedecer suas ordens, pois não era desafiadora e audaciosa como a irmã. 


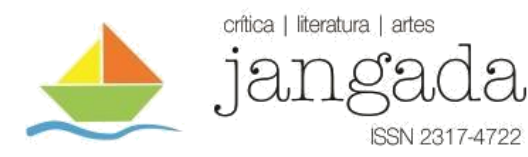

Após o casamento, Nazneen muda-se para Londres, uma sociedade com mais possibilidades para as mulheres; ao passo que Hasina continua residindo em Bangladesh. Por ser passiva, Nazneen se vê dominada e explorada pelo marido, pois Chanu precisava mais do que uma esposa, ele precisava de uma servente. E era isso que Nazneen era, uma parceira submissa que se prestava aos serviços mais humilhantes: "Nazneen estava ajoelhada ao lado dele com uma gilete na mão. Estava na hora de cortar os calos do seu marido de novo. Ela cortou a camada de pele, a parte dura em volta do núcleo amarelo, e juntou os pedacinhos de pele morta na mão.” (ALI, 2004, p. 36).

Nota-se que a protagonista por ser criada pelos moldes patriarcais islâmicos, não se percebe como vítima do sistema dominante, e sim como uma esposa ideal, simbolizando a mulher passiva e subalterna, que fazia trabalhos degradantes, pois era valorizada e reconhecida quando servia à família, como sustentou Beauvoir (1980 II). Esse ato é também uma metáfora da posição da mulher na ordem social e religiosa, pois a posição que Nazneen se encontra, ajoelhada aos pés do marido, é justamente a posição que o sistema dominante designou para a mulher: submissa, dominada e abaixo do homem.

Essa situação começa a mudar quando Nazneen começa a confrontar o marido. $\mathrm{O}$ primeiro ato subversivo da protagonista ocorre quando, pela primeira vez, ela sai de casa sozinha e anda por Brick Lane, o bairro mais próximo a seu apartamento, desafiando as ordens do marido e tentando fugir de suas amarras e, sobretudo, procurando ser percebida e ouvida:

Nazneen caminhou. Ela caminhou até o final de Brick Lane e virou à direita. Quatro quarteirões adiante, ela atravessou a rua e entrou numa rua lateral. [...]. Um tremor de medo - ou seria excitação? - Percorreu suas pernas. [...]. Ela se virou e deu um encontrão num homem que carregava um copo plástico cheio de chá quente que derramou no braço dela. [...] Ele disse alguma coisa. Nazneen reconhecia hindi quando ouvia, mas não compreendia. [...] Ela tornou a sacudir a cabeça e disse "Desculpe". E ele balançou a cabeça solenemente e afastou-se. Aí começou a chover. E apesar da chuva, e do vento que fazia a chuva açoitar seu rosto, e apesar da dor no tornozelo [...] ela começou a se sentir um pouco contente. Ela tinha falado, em inglês, com um estranho, e tinha sido compreendida e notada.”. (ALI, 2004, p. 52-57)

Nazneen, pela primeira vez, se sente atuante e fica confiante, pois apesar de não saber falar quase nada em inglês, ela consegue se comunicar com alguém. Isso é irônico, porque ela se sente notada com uma coisa pequena, que ela poderia fazer no dia a dia, mas seu marido não 


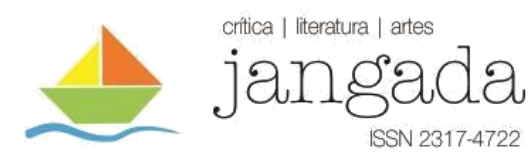

permite isso, uma vez que ele não dava espaço para ela ser notada ou para expressar o que sentia. Na rua, Nazneen se alegra por ser compreendida, o que deveria ocorrer dentro do casamento, pois ela devia se sentir importante, ao menos para o parceiro, contudo isso não acontece.

A ideia de que fora de casa ela se sente mais notada do que dentro de casa representa como os casamentos arranjados no meio muçulmano, quase sempre, eram um fracasso para as mulheres, pois estas não podiam desenvolver sua subjetividade. Portanto, é um símbolo do casamento como prisão. Beauvoir (1980 I) reitera que os homens se nomearam como dignos de todas as práticas sociais, enclausurando as mulheres a pequenos espaços dentro de casa, submetendo-se às exigências do marido, o que acabava se tornando exaustivo para elas, tornando-as, na maioria das vezes, infelizes.

Em contraponto com a irmã, se encontra Hasina, pois enquanto Nazneen está vivendo pequenas liberdades, ela tenta se libertar de um casamento violento, pois sofre agressões físicas e psicológicas por parte do marido. Por ocuparem o papel central no casamento, muitos homens machistas impõem que as mulheres sejam sempre passivas, não aceitando que elas se igualem a eles, muito menos sejam independentes ou tenham alguma liberdade social. Hasina passa por isso e convive, diariamente, com um homem extremamente machista, o que a faz buscar novas soluções para sua vida, como quando comunica a irmã que fugirá do marido: "Irmã agora tenho notícias. De manhã logo depois que o marido sair para trabalhar eu vou embora para Daca." (ALI, 2004, p. 55). Hasina, por ser jovem e sonhadora, não sabe o que a sociedade reserva para uma mulher separada, que fugiu dos pais e depois do marido.

Já a situação de Nazneen muda cada vez mais, porém de forma positiva, pois o desejo dela de aprender inglês faz com que ela crie coragem e confronte o marido, mas ao insistir sobre essa questão, ela é limitada pelo marido, que usa desculpas para mantê-la dentro de casa e a proíbe, de forma indireta, de estudar:

- Razia vai para a escola aprender inglês.

- Ah, que bom.

- Talvez eu pudesse ir com ela.

- Bem, talvez. - Ele não ergueu os olhos do livro.

- Então eu posso? [...]

- Você vai ser mãe. [...] - Isto não irá mantê-la suficientemente ocupada? E você não pode levar um bebê para a escola. Bebês têm que ser alimentados; têm que ser trocados. Não é assim tão simples. Ir para a escola e pronto. 


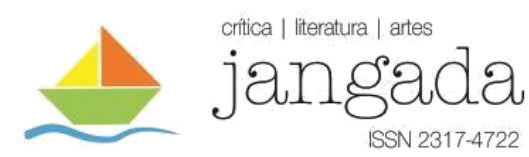

- Sim - disse Nazneen. - Estou vendo que não é. (ALI, 2004, p. 72-73)

Percebe-se que, com este diálogo, Chanu usa estratégias de dominação, pois manipula Nazneen com o filho, mas, mesmo sem o filho ela ainda não poderia aprender inglês, ou qualquer outra coisa. Ele a lembra de suas obrigações como esposa e mãe, fazendo com que ela fique presa em um ciclo vicioso e contraditório que se retroalimenta, em que o homem o intensifica com seus pronunciamentos, pois uma mulher deve se casar e ter filhos, mas quem tem filho não estuda, porque tem que cuidar do filho. É notável que o ciclo vicioso, do qual as mulheres são reféns, é uma tática para mantê-las na opressão, dependentes dos maridos, pois não são os filhos ou as tarefas domésticas que as impediam de estudar e sim os próprios maridos. Na fala de Nazneen: "estou vendo que não é”, percebe-se que há ironia, evidenciando que ela sabe que é Chanu quem vai impedi-la de estudar e não o filho, e que sua situação com o marido é que "não é tão simples".

Quando, novamente, Nazneen recebe as cartas da irmã, fica sabendo que Hasina consegue um emprego de costureira e vai morar nos apartamentos de um senhor chamado Chowdhury. O que ela não sabe é que a pobreza e a inocência de Hasina a levam a acreditar que esse senhor tem boas intenções com ela, pois, logo que foge do marido, ele a ajuda, aparentemente, sem intenções. Como é relatado por ela: "O sr. Chowdhury me diz para fazer as malas e não me preocupar. [...] Ele é pai para mim. Sempre diz "Qualquer coisa que precisar. Toda vez que tiver com problema. Me procure". Ele é este tipo de homem. Todo mundo o respeita." (ALI, 2004, p. 139).

Porém, no transcorrer da narrativa, percebe-se que as intenções dele são outras: "Mas se eu tivesse filha formosa como você para esfregar meus pés eu seria um homem feliz. Pai eu vou esfregar pés. Eu digo a ele. Tiro sandálias feliz de fazer pequena coisa por ele. Ele parece ficar contente." (ALI, 2004, p. 147). Por acreditar que era fraca e que os homens que a ajudavam era apenas por bondade, Hasina deixa o senhor Chowdhury se aproximar dela, e também porque buscava a proteção de um homem, uma vez que ela mesma o nomeia de pai. Porém, na maioria das vezes, esses homens a buscavam por desejo sexual, como nessa situação, em que esse senhor tenta se beneficiar, fingindo ser protetor de Hasina. Wollstonecraft (2016) relata que isso ocorreria porque as meninas eram estereotipadas como fracas, que sempre precisariam de um homem para seu bem-estar.

Quando Hasina deixa um colega de trabalho a acompanhar até sua casa, ela fica malvista na fábrica em que trabalha: "Eu estou malvista na fábrica. Tem uma semana que me evitam. Eu vou sentar com as outras na hora do almoço e elas fazem silêncio." (ALI, 2004, p. 150). 


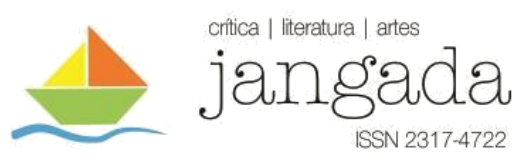

Identificam-se, mais uma vez, ideias contraditórias para punir as mulheres, pois Hasina, por deixar Abdul a acompanhar até em casa, é evitada por todos do local de trabalho, mas ele que insistiu em acompanhá-la não recebe nenhuma punição, demonstrando que os julgamentos sociais e morais recaem apenas sobre a mulher.

Beauvoir (1980II) concorda que para a sociedade, a reputação masculina é imaculável, já para as mulheres sua reputação é condenável quando acontece essa duplicidade: do homem que procura e da mulher que cede. Percebe-se que é irônico que ela seja taxada de prostituta, enquanto ele seja até parabenizado: "Espero do lado de fora da porta ele ser demitido e ir comigo para casa. Ouço o gerente dizer "garota bonita eh? Vocês rapazes! Precisam praticar um pouco antes de casar eh?”. Ele ri.” (ALI, 2004, p. 153). Essa fala do gerente exemplifica as posições sociais de gênero no mundo islâmico, em que o homem pode ter relações sexuais antes do casamento, enquanto a mulher não pode sequer ficar sozinha com um homem.

Quando o sr. Chowdhury fica sabendo sobre o acontecido na fábrica, ele reivindica seu direito sobre o corpo de Hasina, pois crê que pagou por isso, já que a deixava pagar apenas metade do aluguel do quarto em que morava. E Hasina, por não saber como se defender, por ter menos força física, e por acreditar que estava pagando pelo que fez, uma vez que as meninas são ensinadas que a culpa é sempre da mulher, é estuprada:

Ele anda pelo quarto segurando lampião. Eu saio do caminho. Tento me esconder no escuro. A bengala dele me acha. Minhas pernas com medo. Ele grita de novo. "O que foi que você fez comigo? Trepando com cada um daqueles filhos-da-puta da fábrica! Eles deram teto para você? Eles trataram você como filha? O que eles deram para você? O que é que eu ganho? [...]. Então ele tira calça. [...]. É isso que acontece e depois eu choro. O tempo todo pensando que minha vida é amaldiçoada [...]. Tudo que acontece é por minha culpa. Eu escolho o meu marido. Eu abandono ele. Eu vou para a fábrica. Eu deixo Abdul me acompanhar. Sou eu que estou morando aqui sem pagar" (ALI, 2004, p. 157)

O discurso do senhor Chowdhury faz Hasina acreditar que realmente é a culpada pelo o que está acontecendo e não ele, que a estupra. A sociedade patriarcal protege atitudes masculinas, com suas ideias ambíguas de como devia ser uma mulher aceitável, pois se ela não tivesse tomando decisões próprias, estaria segura. Bourdieu (2002) expõe que essas ideias contraditórias eram incutidas dia após dia nas meninas, sem que elas percebessem, até afirmarem que era o correto seguir tal modelo. Assim, são por causa desses discursos ilógicos 


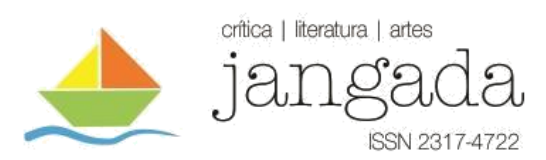

que muitas mulheres viveram oprimidas, esse fato é representado nas relações que Hasina tem, a personagem, inicialmente, insubordinada, é dominada pelo sistema opressor, que rebaixa e pune as mulheres que desobedecem às ordens do patriarcado.

Embora tenha apanhado do primeiro marido, sido demitida injustamente da fábrica que trabalhava, julgada, posteriormente, estuprada e obrigada a se prostituir, Hasina acha que é ela que não presta: "Eu sou uma mulher ordinária. Eu não sou nada. Não tenho nada. Eu sou tudo o que tenho." (ALI, 2004, p. 162). Isto acontece porque ela não tem consciência do que o mundo machista lhe fez, de como este a prejudicou, fazendo-a crer que tudo o que aconteceu foi por sua culpa.

Nota-se que cada vez mais, Hasina tem menos consciência do mundo, ao passo que Nazneen faz um caminho inverso, pois vai adquirindo consciência da sua situação e se descobrindo como sujeito autônomo. Sabe-se que a culpa não é de Hasina, dado que a realidade das duas é diferente, enquanto Nazneen está em uma sociedade que lhe apresenta alternativas de sobreviver sozinha, Hasina está em uma sociedade com costumes mais rígidos, que não permite sua ascensão.

Deste modo, enquanto Hasina vai decaindo por causa da influência negativa da sociedade, visto que esta não a permite ter um emprego que não se encaixe com as tarefas domésticas, e a pune por ter relações sexuais fora do casamento. Nazneen vai desenvolvendo qualidades e despertando mais desejos, como, por exemplo, o de conhecer seu próprio corpo: "Caminhando sobre a colcha [...] Levantou ainda mais a saia e examinou suas pernas no espelho. [...] Ela abriu os olhos e ficou impressionada com suas pernas marrons e esbeltas." (ALI, 2004, p. 135). Observa-se que a protagonista do romance está evoluindo, se conhecendo, descobrindo prazeres, quebrando as barreiras dos limites impostos pela ideologia patriarcal. Nazneen representa as mulheres que buscaram conhecer seus corpos e seus desejos, apenas depois de casadas, conforme começaram seus processos de autonomia.

Conforme Nazneen vai ganhando confiança em si mesma, ela demostra novas vontades, apesar de nunca ter conseguido estudar por causa de Chanu, ela almeja trabalhar. Mesmo censurando a esposa, e por estar desempregado, Chanu compra uma máquina de costura para ela. Se eles estivessem em Bangladesh e Chanu tivesse um bom emprego, Nazneen não teria a possibilidade de trabalhar, em Londres ele só permite que ela trabalhe porque a situação da família começa a ficar desesperadora.

O trabalho propicia a ela outros meios de conhecer novas pessoas, passa a ter novos desejos e vontades, e quando conhece Karim, pela primeira vez, sente desejos sexuais intensos. 


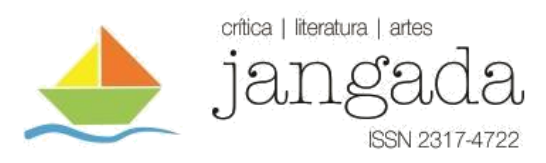

Depois de um tempo buscando roupas para a mulher costurar, Chanu desistiu dessa ocupação, porque tinha conseguido um emprego como taxista, então permitiu que outra pessoa fizesse esse trabalho, por conseguinte "[...] apareceu um novo intermediário. Karim, com uma pilha de jeans sobre o ombro largo. Foi assim que ele entrou em sua vida." (ALI, 2004, p. 199). Pela primeira vez, ao conhecer Karim, Nazneen se sente atraída por um homem e começa a ter desejos diferentes, de liberdade, de se arrumar para alguém, de sentir prazer e, principalmente, de se permitir.

O que se sabe de Hasina em seguida, é que ela vai decaindo cada vez mais, pois acaba indo morar em um abrigo para "mulheres perdidas", mas logo é tirada de lá e vira empregada doméstica de uma família rica: "Eles me tiraram da Casa de Mulheres Decaídas uma hospedaria para desamparadas em Hazaribagh [...]. Minha obrigação em casa é cuidar das crianças limpar lavar pratos lavar roupa fazer compras e coisas assim.” (ALI, 2004, p. 210-211). Nisso, evidencia-se o quanto a sociedade é cruel para as mulheres, pois não permite que elas participem do meio social sem ter um homem do lado para representá-las.

Beauvoir (1980 II) compreende que a mulher só tem reconhecimento social quando é casada e tem filhos. Por ser separada e ter ficado nesse abrigo e depois ter sido tirada por uma família tradicional, Hasina não percebe a crueldade da sociedade e nem enxerga o quanto era explorada. Isso mostra que Hasina, por não ter contato com outra realidade, como Nazneen, internalizou como verdadeiros os valores de sua sociedade que culpabiliza as mulheres quando estas são vítimas.

Ao contrário disso, Nazneen estava ascendendo como mulher, dona de suas vontades. Pela influência de Karim e por vontade sua também, Nazneen aprende um pouco mais de política, ela começa a fazer parte de reuniões realizadas por ele, para defender os direitos da comunidade mulçumana que também era excluída do resto da cidade: "O conhecimento dele a envergonhava. Ela aprendeu sobre seus irmãos e irmãs mulçumanos. [...] Ele a deixava envergonhada. E ele a excitava.” (ALI, 2004, p. 231), pois Karim dava a Nazneen o que Chanu não era capaz de fazer, ele a notava, ele a ouvia, queria sua opinião, queria que aprendesse, discutisse. Ele a via como sujeito e se importava com o que sentia.

Porém, Chanu começa a falar, com mais frequência, em retornar para Bangladesh, e isso faz Nazneen pensar sobre sua vida. E quanto mais pensava, mais atormentada Nazneen ficava. Certa noite, por não conseguir dormir, ela tenta se distrair fazendo atividades domésticas, mas isso a faz ter alucinações, ela vê a imagem de sua mãe falando: “- Quando você era pequena, costumava me perguntar: “Amma, porque você chora?” Meu bebê, agora 
você sabe? [...] - É isto que as mulheres têm que suportar[...]. - É fácil. Você só tem que suportar." (ALI, 2004, p. 306-307). Por não ter escolhas, as mulheres eram ensinadas que precisavam suportar e não tomar decisões coerentes que acabassem com seus sofrimentos.

Nazneen não tinha certeza sobre o que fazer, não sabia se obedecia ao marido, se criava coragem de se rebelar e ficar em Londres, ou se ficava com o amante, mas ela não queria apenas suportar. Esse tormento em sua mente simboliza seu inconsciente se debatendo sobre o que fazer, pressionando-a a tomar uma decisão, antes que fosse tarde. Essas oscilações, medos e incertezas da personagem correspondem à própria figuração de personagens femininas e a escrita de autoria feminina, que sofreram recuos e avanços até se firmarem na sociedade.

Quando obteve consciência de sua condição, Nazneen resolveu não se preocupar mais com o marido e nem sobre o que ele iria pensar ou fazer em relação ao seu amante, mas ao contrário de condenar ou maltratar a esposa, foi a vez de Chanu permanecer em silêncio: "Uma vez, depois da jornada dupla, Chanu chegou em casa de tarde enquanto Karim estava usando o computador. [...] Ele vestiu o anorak e, embora não tivesse para onde ir, tornou a sair." (ALI, 2004, p. 356). Isso ocorreu, porque Chanu ainda idealizava uma família perfeita e não queria perder a esposa. Por isso, ele tenta arrumar dinheiro para a viagem, pois acreditava que de volta à antiga sociedade Nazneen voltaria a ser a mesma esposa, calada e submissa.

Como homem mulçumano preso a sua cultura e machista, esperava-se que ele fosse violento, mas a atitude de Chanu mostra o contrário, que ele não representa, plenamente, o homem mulçumano. Talvez por também ter contato com outra realidade, isso o tornou mais "avançado" do que eles, embora ainda fosse muito machista, demonstrando que o contanto com uma cultura mais liberal, molda tanto a mulher quanto o homem.

Ao perceber que pode mudar sua condição, a trajetória de Nazneen a faz refletir sobre a vida que teve, todas as limitações por sempre seguir as leis patriarcais, e ficar emudecida acreditando que era seu destino ser infeliz fazendo o que o marido ordenava. Isso a faz assumir sua posição de sujeito capaz de questionar e tomar decisões adequadas para certas situações: "Eu vou decidir o que fazer. Eu vou determinar o que vai ser de mim. Sou eu quem vai fazer isso." (ALI, 2004, p. 387), evidenciando que Nazneen toma as rédeas de sua vida e decide fazer escolhas sem a influência da sua cultura ou do marido, pensando em si. Dessa forma, por ser dona de suas escolhas, ela decide não aceitar o pedido de casamento de Karim, rompendo com ele:

- Nós não podemos nos casar.

- Não imediatamente - disse Karim 
- Nunca.

- O que você quer dizer com "nunca"? - Ele pareceu irritado. Chutou o chão com a bota.

- Eu não quero me casar com você - disse Nazneen, olhando para o malabarista. - É isso que quero dizer. [...]

- Se você está sendo sincera, tem que me dizer de novo, olhando para mim.

- Eu não quero me casar com você. (ALI, 2004, p. 430)

Nazneen queria ser livre para fazer o que quisesse e sabia que Karim, como marido, teria o mesmo comportamento dos outros homens que limitavam suas esposas, pois ele também tinha sido educado conforme os modelos de marido que era estabelecido pela sociedade patriarcal islâmica: "Como Karim a via? Um artigo genuíno, ele disse. Ela era um artigo genuíno. Uma esposa bengalesa. Uma mãe bengalesa. Uma ideia de lar. Uma ideia de si mesmo que ele via nela." (ALI, 2004, p. 433), ou seja, a mesma ideia que Chanu tinha dela: "Como eu digo, é uma garota de aldeia: nada estragada.” (ALI, 2004, p. 20), relatando que ela era uma moça simples e que por isso seria uma boa esposa e mãe bengalesa.

E, no fim, Karim só se preocupava em ouvi-la quando ela era uma conquista, pois como marido seria igual Chanu. Demonstra-se o quanto Nazneen se torna uma mulher fortalecida, pois agora ela sabia que para ser dona da própria vida só teria que tomar decisões coerentes, e que para ser feliz, ela não precisava de um homem, pois a sociedade na qual estava vivendo lhe permitia muito mais do que ficar só enclausurada se dedicando a tarefas domésticas e aos filhos.

Quando resolveu contar sobre sua decisão para o marido de não ir para Bangladesh, ele não tinha argumentos para persuadi-la a voltar atrás, pois sabia que ela estava decidida: “As lágrimas dele escorreram pelos seus dedos. - Então você vai comigo? Você vai? - Não - ela sussurrou [...]. Eu não posso ir com você.” (ALI, 2004, p. 456), e foi dessa forma que Nazneen conquistou sua autonomia, pois ela não tinha mais nenhum homem para influenciar ou tomar decisões por ela. De chefe de família que decidia tudo: ela não podia aprender inglês, não podia trabalhar, nem sair e se recusava a ajudar Hasina, Chanu cai para a posição que Nazneen ocupava antes, pois agora é ela quem toma a decisão pela vida dos dois. Com isso, evidenciase uma inversão dos papeis tradicionalmente masculinos e femininos na cultura islâmica.

Como já dito anteriormente, por ter ficado em uma sociedade com valores rígidos, Hasina é malvista, passa fome, se prostitui e não consegue mudar sua condição e nem se estabelecer como sujeito, pois é sempre tratada como objeto. O que se sabe de Hasina, no fim, é que ela fugiu com o cozinheiro da casa no qual ela era empregada, como Chanu conta para 


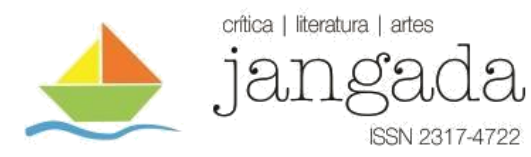

Nazneen ao telefone: “- O patrão dela me procurou. Ela desapareceu junto com o cozinheiro. Eles fugiram juntos." (ALI, 2004, p. 467). Percebe-se que Hasina se mantém determinada na busca por uma vida melhor, mesmo sua sociedade a reprimindo. Entretanto, ela ainda acreditava que a felicidade se concretizava com um homem ao seu lado, num movimento oposto ao de Nazneen, que decidiu não querer nem o marido nem o amante, sentindo-se plena e feliz sem nenhum parceiro amoroso e sexual.

Assim, por ser inserida numa sociedade mais flexível que a sociedade mulçumana, é notável a ascensão de Nazneen, que passa de uma mulher submissa para uma mulher insubordinada, pois de calada e passiva, ela passou a questionar, a ter autoridade dentro de casa, e a lutar por direitos, principalmente, o de ser ouvida e respeitada conforme suas decisões, refletindo sobre seu lugar no mundo e construindo uma nova identidade. Por outro lado, evidencia-se a decadência de Hasina, que pela rígida cultura de sua sociedade não consegue adquirir consciência do quanto é oprimida.

\section{CONCLUSÃO}

É perceptível que a obra reflete sobre a sociedade como preponderante para definir os papéis das mulheres, uma vez que Hasina, por ter ficado em uma sociedade com costumes mais rígidos e fixos, não conseguiu escapar das imposições patriarcais, pois ficou à margem, sendo julgada, constantemente, como uma mulher perdida. E por essa influência negativa sobre ela, Hasina passa toda a narrativa sofrendo, por causa dos homens violentos que se envolve e da sociedade que não a ampara. E por mais que ela tivesse uma essência feminista, isso só permanecia em sua essência, porque ela não conseguia colocar em prática, não conseguia lutar por direitos, por liberdade de ser quem queria, se todos a sua volta a rebaixavam e a faziam acreditar que estava errada, que não conseguiria sair da sua condição.

Ao contrário disso, Nazneen que, inicialmente, não apresenta insubordinação, e é emudecida e passiva às ordens patriarcais, descobre e desenvolve desejos e encontra oportunidades no decorrer de sua trajetória, mas isso acontece porque ela foi inserida em uma outra sociedade que permite mais para as mulheres, dando possibilidades e liberdades para seus crescimentos enquanto sujeitos. Com isso, Nazneen busca melhores oportunidades, trabalhando, aprendendo com as novas situações, enfrentando o marido e desenvolvendo sua autonomia. Assim, percebemos que Nazneen, como protagonista, teve uma evolução maior, se tornando uma mulher insubordinada, moderna e dona da sua vida. 


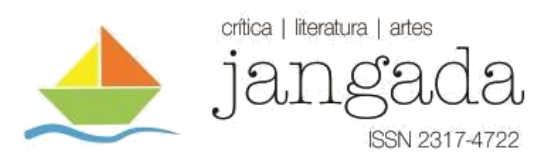

O romance mostra, por meio de uma análise baseada na crítica feminista, de que forma as mulheres mulçumanas são representadas na literatura. Monica Ali, como mulher bangladeshiana, denuncia a forte internalização dos discursos patriarcais e demonstra os estereótipos reducionistas que limitam as mulheres mulçumanas. A protagonista é representada como uma mulher forte, que luta por um espaço mais igualitário dentro da sociedade sexista, assim como na vida real, em que as mulheres tiveram que lutar por seus direitos, constituindo uma identidade feminina. Entende-se que ambas as sociedades são sexistas, porém uma é mais flexível a mudanças que a outra.

Demonstra-se, também, o poder da literatura sobre mulheres e feita por mulheres, pois, além da luta por espaço social, as mulheres lutaram por um espaço literário também. É notável que para o desenvolvimento de uma mulher autônoma, dona de si e de suas vontades, é preciso espaço e oportunidades na sociedade em que vive, naquilo que Woolf chamou de "um teto todo seu", em que para se ter liberdade, uma mulher precisa de uma renda financeira e um espaço próprio.

\section{REFERÊNCIAS BIBLIOGRÁFICAS}

ALI, Monica. Um lugar chamado Brick Lane. Tradução de Léa Viveiros de Castro. Rio de janeiro: Rocco, 2004.

AUSTEN, Jane. Razão e Sensibilidade. Tradução de Mariana Menezes Neumann. Rio de Janeiro: Best Bolso, 2011.

BEAUVOIR, Simone de. O Segundo sexo: fatos e mitos. Tradução de Sérgio Milliet. Rio de Janeiro: Nova Fronteira, 1980 I.

. O Segundo sexo: a experiência vivida Tradução de Sérgio Milliet. Rio de Janeiro:

Nova Fronteira, 1980 II.

Biografia de Monica Ali. British Council, Reino Unido: Doubleday (online). Disponível em: $<$ https://literature.britishcouncil.org/writer/monica-ali $>$ acesso em: 28 jun. 2020.

BOURDIEU, Pierre. A dominação masculina. Tradução Maria Helena Kühner. Rio de Janeiro: Bertrand Brasil, 2002.

BRONTË, Charlotte. Jane Eyre. Rio de Janeiro: Paz e Terra, 1996.

LUFT, Lya. A Sentinela. São Paulo: Siciliano, 1994.

MATOS, Maria Izilda Santos; SOIHET, Rachel. O corpo feminino em debate. São Paulo: Editora Unesp, 2003.

MICHEL, André. O Feminismo: Uma abordagem histórica. Rio de Janeiro: Zahar, 1982.

Jangada | nr. 16, jun/dez, 2020 | ISSN 2317-4722

356 |P á g in a 
MILlETT, Kate. Política Sexual. Tradução de Alice Sampaio, Gisela da Conceição e Manuela Torres. Lisboa: Publicações Dom Quixote, 1970.

PERROT, Michele. Minha história das mulheres. Tradução de Angela M. S. Corrêa. São Paulo: Contexto, 2007.

PINTO, Paulo Gabriel Hilu da Rocha. Islã: religião e civilização. Uma abordagem antropológica. Aparecida, SP: Editora Santuário, 2010.

SAFFIOTI, Heileieth. Gênero, patriarcado e violência. São Paulo: Fundação Perseu Abramo, 2015 .

SHOWALTER, Elaine. A Literature of their Own: British Women novelists from Brontë to Lessing. New Jersey: Princeton Up, 2014.

SILVA, Dirceu Alves da. A mulher mulçumana: Uma visão panorâmica de Meca a São Paulo. Dissertação (Mestrado em Ciências da Religião) - Universidade Presbiteriana Mackenzie, São Paulo, 2014.

TRUZZI, Oswaldo. Família Árabe Muçulmana em São Paulo. In: Revista de Ciências Sociais, Rio de Janeiro, n.1, 2008, p. 37 a 74.

WOLLSTONECRAFT, Mary. Reivindicação dos direitos da mulher. Tradução de Ivania Pocinho Motta. São Paulo: Boitempo, 2016.

WOOLF, Virginia. Um teto todo seu. Trad. Vera Ribeiro. São Paulo: Círculo do Livro, 1990. 